\title{
Prostitution Harms Women Even if Indoors.
}

$1-31-05 a$

To cite: Farley, Melissa (2005) Prostitution Harms Women Even if Indoors: Reply to Weitzer. Violence Against Women 11 (7): 950-964 July 2005

“...I cannot avoid expressing my deepest grief in learning of the efforts of proprostitution organizations to decriminalize the act of purchasing a person for sex. It is simply not possible for me to convey in words the intense pain and struggle I have endured as a result of my experience in prostitution.

"I chose to work as a prostitute because I believed I had no other options. I entered prostitution due to extreme emotional and financial stress and a lack of a supportive family system.

"Because I was white and not exhibiting obvious signs of a serious drug addiction, I was able to work in "upscale" massage parlors in [California]. While street-walking was extremely dangerous, it is completely erroneous to assume that the brothels were immune to violence. There were incidents of attempted strangulation and forceful restraint. Customers would intentionally remove condoms against the prostitute's wishes. They often requested bondage and acts of sadism. If the managers (madames or pimps) felt that the customer's request was reasonable, the prostitute was obligated to comply, or find another house to work in.

"I now choose to be an advocate for the right of prostitutes to be free of the forces that restrict their escape. I ...urge all compassionate people to consult the data and research that has been conducted regarding the demographics and desires of the women, men, children, and transgendered who are in prostitution. This ... research illustrates that those involved in prostitution advocacy represent a very small minority of the prostitute population."

Written by a survivor who chooses to remain anonymous

\section{Different perspectives on prostitution}

All science is infused with values, whether it's stem cell research, research on the psychological effects of colonization of one people by another, or research on the effects of incest or rape or prostitution. The issue is not whether research is permeated with values - it always is - but whether those values are made explicit as opposed to being

vaguely stated or deliberately concealed. Baral, Kiremire, Sezgin and I wrote: "We initiated this research in order to address some of the issues that have arisen in discussions about the nature of prostitution. In particular: is prostitution just a job or is it a violation of human rights? From the authors' perspective, prostitution is an act of violence against women: it is an act which is intrinsically traumatizing to the person 
being prostituted" (Farley Baral et al 1998). We made our perspective and hypotheses transparent. We then made our procedures and the ways in which those hypotheses were tested sufficiently explicit for others to replicate the study. As Weitzer noted, our results were not always as we had predicted.

After a decade of research on prostitution that includes more than 854 interviews with people in 9 countries, I wrote an article in Violence against Women that was as Weitzer said, a "wide-ranging" discussion about prostitution legalization and decriminalization. Along with many others, I concluded that prostitution was multitraumatic with extremely high rates of physical and sexual violence perpetrated against people who were vulnerable usually as a result of gender, poverty, previous history of sexual assault, marginalization because of race/ethnicity or a combination of these factors. My coauthors and I concluded: "Our findings contradict common myths about prostitution: the assumption that street prostitution is the worst type of prostitution, that prostitution of men and boys is different from prostitution of women and girls, that most of those in prostitution freely consent to it, that most people are in prostitution because of drug addiction, that prostitution is qualitatively different from trafficking, and that legalizing or decriminalizing prostitution would decrease its harm." (Farley, Cotton, Lynne, Zumbeck et al., 2003).

Weitzer, on the other hand, failed to make his perspective transparent. In fact he is a supporter of indoor prostitution. In his writings, Weitzer has focused on the community disruption caused by outdoor (street or car) prostitution and has supported indoor prostitution. Indoor prostitution includes massage parlors and saunas, brothels, strip clubs, and escort prostitution. Escort prostitution simply means that an ad is placed online or in a newspaper, that she or her pimp has a cell phone, and that there is access to a home or hotel room or car. "High class call girl" prostitution means that more money passes through several peoples' hands in escort prostitution. In a 1994 collection of articles titled In Defense of Prostitution Weitzer published an article about community resistance to street prostitution (Weitzer, 1994). This special issue of The Gauntlet was edited by COYOTE member Carol Leigh who also promotes decriminalization of prostitution. Weitzer views prostitution from the community's perspective. He decries the mess created by used condoms and discarded syringes and the loss of business revenue as a result of a 
neighborhood's "seedy ambiance" and the verbal harassment of nonprostituting women by customers of prostitutes (Weitzer, 1994, p 122).

Dutch researcher Ine VanWesenbeeck (1994, p 33) wrote: "Researchers seem to identify more easily with clients than with prostitutes..." Weitzer does not consider prostitution from the perspective of the prostitute. Rather, he tends to view prostitution either from the perspective of the trick or from the perspective of the nonprostitute community (Adams \& Riley, 2004).

$\underline{\text { Research methodology used by the author and colleagues }}$

Weitzer charges that research exploring the harms of prostitution is riddled with methodological flaws. In fact, our research is methodologically sound and has been replicated. For example, we used a standardized and validated test of posttraumatic stress disorder. We also asked about respondents' histories and demographics with a number of true/false questions. In peer-reviewed psychology journals, questionnaires are rarely included in their entirety although the lead author's contact information is publicized. I have been contacted by numerous researchers, some of whom have independently replicated the methodology I used and subsequently published the results (Baral et al, 1998, Valera et al, 2001, Zumbeck et al, 2003).

Weitzer bemoans our lack of a random sample. As other researchers of prostitution have noted, it is not possible to obtain a random sample of people currently prostituting (McKeganey \& Barnard, 1996). Investigators therefore use a variety of techniques to learn about the experience of prostitution for those in it. Generally, smaller numbers of interviewees limit the generalizability of results. We have reported data from a large number of respondents in different countries and in different types of prostitution.

We described in detail where and how we located respondents. We attempted to reach as diverse a range of people in prostitution as we could, including people of diverse races, cultures, ages, locations where prostituting, and genders. We observed, as others have, that those who were the most harmed or the most vulnerable were not available to us to interview (Vanwesenbeeck, 1994). They are either imprisoned or kept indoors and out of public view. 
But there are additional difficulties in conducting research on prostitution. Although it is likely that funding will be more accessible in the next decade, at this moment in time it is extremely difficult to obtain funding that would permit the expense of random sampling of either women in prostitution or their tricks. Therefore one must interview whomever one can access.

Adam Ruiz, Odette Levy, Barbara Strachan and I have conducted research interviews with tricks and have faced problems with obtaining representative samples. Although some US research on customers of prostitutes interviewed men in diversion programs who solicited prostitutes (Monto \& Hotaling, 1998) we interviewed men who had not been arrested in part because we wished to interview men who bought women in indoor prostitution. Customers who are not in a police-sponsored program tend to exhibit more "john-like” behaviors: all four interviewers encountered verbal sexual harassment from the non-arrested johns while conducting the research.

We encountered other difficulties. Publishers of sex industry magazines such as the Bachelor's Beat in Phoenix are reluctant or unwilling to permit advertisements regarding research on prostitution. For example, I attempted to place a classified advertisement in Bachelor's Beat (January 2005) seeking interviews with customers of prostitutes. The advertisement was refused by the editor. The announcement I was seeking to run in Bachelor's Beat was perhaps considered a threat to the ongoing business of advertising prostitution.

Weitzer states that I have "simply decree[d] that prostitution is violence, a proclamation that is neither verifiable nor falsifiable." He appears not to have read the series of studies that permit me to conclude: "Our findings from 9 countries on 5 continents consistently indicate that the physical and emotional violence in prostitution is overwhelming" (Farley et al, 2003). The 2003 study described the frequency of 6 types of lifetime violence, the number of types of lifetime violence, and rates of PTSD in 9 countries. Weitzer states that he is unclear if my work includes male and transgender prostitution in spite of the fact that I've described inclusion of both these groups in my research (Farley, 1998, Farley, 2003).

Weitzer cites our reports that there was more physical violence in street prostitution than in brothel prostitution in South Africa as evidence against my claim of violence in all 
forms of prostitution. Of course, the fact that some types of prostitution are associated with more severe harm than others does not mean that the marginally less harmful types of prostitution are not harmful at all.

Weitzer noted that some of our respondents favored legalized or decriminalized prostitution. Like everyone else, our interviewees minimized the harms of prostitution and they sometimes believed industry advocates' claims that legalization or decriminalization will somehow make them "safer." Sadly, there is no evidence for their belief and much evidence to the contrary.

Indoor prostitution tends to be socially invisible prostitution.

Advocates, researchers. feminist theorists and Weitzer all agree that most prostitution in the US takes place indoors, with a relatively small percentage of prostitution taking place outdoors. Even when prostitution is illegal, tricks are much less likely to be arrested in indoor prostitution since in most jurisdictions police ignore indoor prostitution unless they receive a complaint.

Multi-page advertisements for escort and massage prostitution run daily in metropolitan US newspapers. The Manhattan yellow pages contains 30 pages of listings under "escorts" (Jacobs, 2004). Although prostitution is illegal in locations where it is advertised, newspapers use code words that keep prostitution teasingly veiled and totally accessible: "personal services," "massage," "conversation," "dating," "women seeking men," "introductions," "modeling," "escort services," "personal businesses," "private services," "DeSade," "phone entertainment," adult fun," "TV/TS," and on and on.

The relative harms of indoor and outdoor prostitution have been debated. There is some research evidence that suggests that outdoor prostitution may subject women in prostitution to higher rates of physical violence, but according to several studies, the rates of psychological violence among indoor and outdoor prostitution are comparable. In practice, indoor prostitution increases the trick's safety and comfort but it does nothing to decrease psychological trauma for the prostituted woman. In fact, the social invisibility of indoor prostitution may actually increase its danger. When women prostitute indoors, the community is less likely to see them. Homes or apartments are rented for use as brothels for escort prostitution. Sometimes when prostitution is indoors, neighbors do not even know 
that prostitution is occurring next door. No one lodges complaints until neighbors become irritated about a lack of parking space or they become suspicious about the steady stream of men going in and out of the house in 20 minute intervals. In 2004, a brothel with trafficked Asian women operated in a San Francisco neighborhood. No one knew that it was a brothel until federal agents and immigration officials arrested a woman pimp (Wallace, 2004).

\section{Is indoor prostitution safer than outdoor prostitution?}

Most research comparing indoor to outdoor prostitution has addressed only physical violence. Starting on page 1099, I described more than 10 studies that address similarities and differences between indoor and outdoor prostitution. Several studies found either no differences between the two or increased psychiatric symptoms among women in strip club prostitution.

Documenting the profound emotional distress experienced by women in two kinds of prostitution, a Canadian study compared strip club and street prostitution. The authors found that women prostituted in strip clubs had higher rates of dissociative and other psychiatric symptoms than those in street prostitution (Ross, Anderson, Heber \& Norton, 1990). In a separate study we compared strip club/massage, brothel, and street prostitution in Mexico and found no differences in the prevalence of physical assault and rape in prostitution, of childhood sexual abuse, or symptoms of PTSD. We also found no differences in the percentages of Mexican women in brothel, street, or strip club/massage prostitution who wanted to escape prostitution (Farley, Cotton, Lynne, Zumbeck, Spiwak, Reyes, Alvarez, \& Sezgin, 2003). (Farley, 2004, p 1100)

Yet Weitzer states that "Indoor prostitution typically involves much less exploitation, much less risk of violence, more control over working conditions, more job satisfaction, and higher self-esteem." (Weitzer, 2004). He defines exploitation as extreme physical coercion, ignoring psychological violence. He fails to define what types of control are exercised over the "working conditions" of prostitution. Job satisfaction and self-esteem are similarly undefined. He also fails to notice the silence created by the lack of research on this subject.

In a recent newspaper editorial, Weitzer proposed a two-tiered system of prostitution decriminalization. He recommended keeping prostitution indoors and out of sight while at the same time prosecuting those committing the "nuisance prostitution" that happens 
outdoors, on the street, and in plain view. These are critical issues because the current argument of sex industry advocates is that decriminalization will mysteriously provide prostitutes greater safety and greater job satisfaction. Just how safety will be brought about by decriminalization of prostitution has never been clearly articulated, much less empirically assessed.

Weitzer's support of massage parlor prostitution - one type of indoor prostitution surfaced in the context of newspaper reports about a series of arrests connected with massage parlor prostitution in Louisville, Kentucky. Although there are numerous reports that residential brothels and massage parlors are locations to which women are secretly trafficked from other countries and used in prostitution (Wallace \& Zamora, 2004; Matier \& Ross, 2004, Coughlin, 2004, Dopp, 2003), Weitzer has argued that a police focus on massage parlors is unwarranted from the standpoint of public safety (Adams \& Riley, p 2). Does the public include women trafficked into prostitution? Legal service agencies for immigrants, battered women's shelters in Louisville, and federal agencies are aware of criminal trafficking networks that move Asian and Latin American women from one indoor prostitution location to another on a Midwest prostitution/trafficking circuit (see $<$ http:www.PolarisProject.org $>$. Women and children can be controlled in indoor prostitution in ways that they can not be controlled on the street. They can be locked in their rooms, heavily drugged, restrained, and beaten. Pimps who run indoor prostitution are no less dangerous than pimps who are visible on the street.

Weitzer nonetheless supports men's rights to access women indoors: "Street prostitution is the problem; indoor prostitution is much less of a problem. " "I would lean toward saying that massage parlors - especially if they do not advertise in terms of signage and are fairly invisible - have a positive effect in terms of providing a service that clearly men want..." (Weitzer, 2004). This comment fails to account for the empirically demonstrated psychological harm of prostitution wherever it is perpetrated. Despite this evidence of harm, Weitzer sympathizes with and sides with the needs of the trick.

If we read between the lines, techniques for harm reduction in prostitution are indicative of the physical and emotional dangers of indoor prostitution. The same sexually invasive dehumanization occurs, regardless of the physical location of prostitution (Anderson, in press, p 13) For example, a San Francisco organization suggests: "be aware 
of exits and avoid letting your customer block access to those exits," "be aware of where your client (trick) is at all times, as much as possible," "shoes should come off easily or be appropriate for running in," and "avoid necklaces, scarves, across-the-body shoulder bags or anything else that can be accidentally or intentionally be tightened around your throat" (St James Infirmary, 2004, p 172). Regarding negotiation with tricks, the COYOTE occupational safety recommendations are:

Have a time limit for each service - if a customer can't come within a reasonable period he's costing you money by preventing you from seeing other customers. His failure to get off may also make him agitated or violent.

[And]: Use some mentholated salve (for chapped lips, colds) inside your nostrils - you'll smell the customer less when you give head...

(author's italics) (St James Infirmary, 2004 p 173).

At the $15^{\text {th }}$ International AIDS conference in Bangkok (July 11-16, 2004), several sex worker groups presented information about the occupational health and safety of prostitutes. EMPOWER, a Bangkok organization, instructed women in bar prostitution [a form of indoor prostitution] how to insert and pull out razor blades from their vaginas. This is understood to be a job requirement in the bar show setting where tricks are sexually excited by the possibility of the genital mutilation of Thai women (Jennifer Oriel, personal communication, Melbourne, Australia, August 10, 2004). Describing harm reduction techniques that are bizarre while at the same time banal, New Zealand issued a 100-page guide for sex workers (New Zealand, 2004), which includes information on repetitive strain wrist injuries from handjobs (masturbation of the customer by the prostitute), warnings to carry a flashlight in order to inspect customers for STDs, and instructions for setting up a brothel.

Traditionally, an overall strategy for addressing harm reduction among drug addicts includes three components: 1) reducing the harm (e.g. clean needles so that HIV is not transmitted), 2) reducing the demand (providing immediate and accessible addiction treatment), and 3) reducing the supply (e.g. arresting drug dealers and narcotic traffickers). See for example the Australian National Drug Strategy (2004-2009). When prostitution and sex trafficking are addressed, it is usually only the first, harm reduction, that is considered. Recent thinking, however, is that an overall strategy regarding prostitution/sex trafficking should include all three components, just as all three are included in addressing the 
addictions: 1) harm reduction techniques such as female condom distribution programs 2) measures to reduce the demand for prostitution (arresting tricks) and 3) measures to reduce the supply of women in prostitution (providing what women need in order to get out of prostitution or closing borders in the case of sex trafficking). (Helen McDermott, personal communication, January 26 2005, Canberra, Australia).

Some have alleged that decriminalization of prostitution reduces its harm. The City of San Francisco has recently begun implementing de facto decriminalization of indoor prostitution by transferring supervision of massage parlors from the police department to the health department. Inspections of massage parlors will be much like inspections of restaurants. By removing police jurisdiction over massage brothels, the City of San Francisco increased the vulnerability of all women in indoor prostitution. Yet some of the dangers of indoor prostitution were revealed in 2004-2005 during hearings held by the San Francisco Commission on the Status of Women (CSW) regarding the "labor and safety conditions of exotic dancers." San Franciscans Terence Hallinan, an attorney for the Mitchell Brothers strip club, and Willie Brown, an attorney for strip club owner Sam Conte, were previously the district attorney and the mayor of San Francisco. Beginning in 1996, Hallinan and Brown defended the rights of sex industry pimps to build private booths in strip clubs. According to testimonies of many women in 2004-2005 before the Commission on the Status of Women, increased privacy in the booths and increased physical contact in strip clubs tends to increase sexual assaults against them. The increased privacy for men in indoor strip clubs has at the same time increased the vulnerability to sexual assault of women in the strip clubs.

Defining prostitution as a job, the CSW floundered in its attempts to discover how they might improve "working conditions" of women in prostitution. Should they recommend that private booths be outlawed, even though some women (who were accompanied by club owners) testified that they made lots of money in the booths? Should they recommend that booths in strip clubs must have no locking door - only a curtain, or that the booths must be videotaped or that the walls of the booths could only be three feet high? Should they install panic buttons in the booths? One woman testified that she was forcibly restrained from pressing a panic button while a customer raped her. Despite evidence of harm, the Commissioners attempted to construct prostitution as a job 
like any other. Yet it was apparent from the women's testimony that the strip club owners and pimps would resist any attempt to limit either prostitution or their profits. The pimps disconnected videocameras, installed locking doors on the booths, and collected 'stage fees' (\$550. per weekend night at the Mitchell Brothers strip club) that put economic pressure on women to prostitute in the private booths rather than just strip but not prostitute, as some women preferred to do. One club owner commented: "We would not be able to make money just with lap dancing. That's not what [customers] come for. They come for a one-on-one experience with a beautiful showgirl" (Romney, 2004.)

\section{The emotional harm of prostitution is especially invisible}

Despite the fact that my article in Violence Against Women presented analyses and research regarding the psychological harm of stripclub and massage prostitution Weitzer, like some others, continues to ignore the psychological experience of those prostituted, focusing only on the physical violence of prostitution.

Although the physical violence of prostitution is brutal and pervasive, it pales in comparison to the emotional trauma of prostitution. Employing egregious stereotypes about women in prostitution, Weitzer has described prostitutes as "hardened to the ways of the street" and "difficult to intimidate" (Weitzer, 1994, p123). On the contrary, my observation over the past decade has been that women in indoor as well as outdoor prostitution often appear shell-shocked and numb with terror (which I suppose could be misinterpreted as "hard" if you're not looking at the situation through her eyes). Attempting to explain what time was like when prostituting on the street, one woman told me that "it's like a second lasts for a year." This slowed-down passage of time occurs in situations that are life-threatening or overwhelmingly stressful.

The "paid rapes" (that's what one woman called the acts she performed for tricks in prostitution; she never called it sex) feel like the same psychological state she was in when her [male relative] sexually assaulted her in childhood. Women in prostitution sometimes reason to themselves, "That's what I am, so why not get paid for it? I might as well get paid for what is going to happen to me again, anyway." Pimps and tricks use that fearful logic to recruit women to prostitution, tapping into her despair and her awareness of the lack of safety from sexual assault in our culture. From decades of 
research, we know the devastating and long-term psychological effects of rape which are not diminished if she is paid for the rape or if the rape is named "working in a massage parlor."

A hallmark of the PTSD that frequently results from prostitution is a chaotic emotional volatility that alternates with numbness. Confused, one woman wrote about her experience in stripclub prostitution:

...Out there, you heard them; they sounded like wolves, you could breathe them. ...my God; there was this wall of sweaty white faces, open-mouthed, glistening with booze, hate and fear. Yes - fear. I used to feel almost detached, sometimes, going through my routine, and - I couldn't help myself - looking into the punters' eyes (the part of me that wasn't scared shitless, that is). And they bewildered me, more than anything else. I felt like stopping the show and saying, "Listen: what's happening here?" (Roberts, p. 83)

As Roberts points out, we have more to learn about prostitution, especially men's thinking about and demand for prostitution. In addition to focusing on tricks, future research should focus on indoor prostitution. It should include descriptions of locations where all research respondents have ever been prostituted. Tricks should always be asked where they have purchased women or men in prostitution. Because a researcher interviews a trick in the street, one cannot assume that his prostitution activities are exclusively street prostitution. He may also purchase women indoors. Similarly, because a researcher interviews a woman in street prostitution, one cannot assume that her prostitution activities have not also included escort or massage prostitution.

Pimps can be women or men. Sometimes pimps deliberately exploit the shame associated with prostituting. Stating that she was not the type of pimp who "enforces the rules with a baseball bat," one New York pimp explained that when one of "her girls" failed to show up for work all day, necessitating cancellation of thousands of dollars worth of appointments, she knew how to make the woman "want to commit suicide by the end of the weekend." In one instance, the pimp telephoned the young woman's boyfriend, informing him that his longtime girlfriend was a prostitute, and prepared to send a CD-ROM of the young woman's promotional pictures (likely pornography) to her family (Jacobs, 2004).

Indoor prostitution above all protects the trick. Men are physically and psychologically safer when prostitution is indoors (1). Weitzer and others who support 
indoor prostitution contrast it with street prostitution on the basis of indoor prostitution's invisibility to the community, sometimes referring to it as "discrete." This perspective strongly reflects the interests of tricks for privacy, anonymity, and constant access to women in prostitution with minimal risk of arrest even in locations where prostitution is illegal. Yet $89 \%$ of 854 women we interviewed said that they wanted to escape prostitution. They did not specify that they wanted to escape street prostitution rather, they wanted escape from all prostitution, including indoor prostitution. Indoor prostitution, like other prostitution, is profoundly harmful.

What is wrong with prostitution cannot be fixed by moving it indoors. The same harms are there whether she's in a trick's house, a back alley, his car, or a room at a hotel. And the same physical violence occurs whether it's in a pimp's massage parlor, the private booth of a pimp's strip club, a pimp's legal brothel, or on a pimp's street turf. The same psychological violence occurs indoors, too - none of that changes based on the location of the prostitution. She still gets called those vicious names while he is masturbating in her, those names that as one woman said, "cut you like a knife" so that she has to get high or she must dissociate in order to tune out the poison. Weitzer's apologetics for and evasions of this reality cannot obscure it and they cannot change it.

$\underline{\text { Notes }}$

1. The author thanks Michelle J. Anderson for discussion of this concept and for editing the paper.

The author thanks Catharine A. MacKinnon for her words and conceptual genius.

\section{$\underline{\text { References }}$}

Adams, J \& Riley, J. (2004) After spas' boom, enforcement affects illicit sex business" Courier-Journal. Louisville, Kentucky. July 11, 2004. p 1-2.

Anderson, M. (forthcoming) All-American Rape. St. John's Law Review.

Ministerial Council on Drug Strategy. The National Drug Strategy: Australia's Integrated Framework. 2004-2009. Canberra, May 2004. Accessed January 25, 2005 at http://www.nationaldrugstrategy.gov.au/pdf/framework0409.pdf

Baral, Isin, Sezgin, Ufuk and Farley, Melissa (1998) The Traumatic Consequences of Prostitution in Turkey. Archives of Neuropsychiatry (Turkey), 35: 1, 23-28. 
Coughlin, M. (2004) Spa workers charged with prostitution. The Philadelphia Reporter January 15, 2004. Accessed Jan 72005 at http://www.thereporteronline.com/site/news.cfm?newsid $=10811271 \& B R D=2275 \& \mathrm{PAG}$ $=461 \&$ dept $\mathrm{id}=466404 \& \mathrm{rfi}=6$

Dopp, T. (2003) Sex slaves smuggled into New Jersey . Express-Times May 1, 2003. Accessed Dec 202004 at:

http://www.nj.com/news/expresstimes/nj/index.ssf?/base/news-2/1051779849166850.xml

Farley, Melissa (2004) "Bad for the Body, Bad for the Heart:" Prostitution Harms Women Even If Legalized or Decriminalized. Violence Against Women 10: 1087-1125

Farley, M., Cotton, A., Lynne, J., Zumbeck, S., Spiwak, F., Reyes, M.E., Alvarez , D., Sezgin, U. (2003) "Prostitution and Trafficking in 9 Countries: Update on Violence and Posttraumatic Stress Disorder” in M. Farley (editor) Prostitution, Trafficking, and Traumatic Stress. Binghamton: Haworth, pages 33-74.

Jacobs, A. (2004) Call Girls, Updated. New York Times October 12, 2004. Accessed November 302004 at $<$ http://www.nytimes.com/2004/10/12/nyregion/12madam.html?ex=1098599063\&ei=1\&en $=20 \mathrm{de} 55812 \mathrm{ce} 4 \mathrm{a} 4 \mathrm{a} 7>$

Matier, P \& Ross, A. (2004) S.F. parlor hit in crackdown on sex-slave trade. San Francisco Chronicle October 25, 2004. page B1.

Monto, M. \& Hotaling, N (1998) "Rape Myth Acceptance Among the Male Clients of Female Street Prostitutes." Presented at the Annual meetings of the Pacific Sociological Association, San Francisco, California.

New Zealand (2004) Prostitutes get 'How To' Guide.

Accessed August 042004 at

$<$ http://www.iol.co.za/index.php?set_id=1\&click_id=29\&art_id=qw1091360343464N24 $5>$

Roberts, N. (1986) The Front Line. London: Grafton Books. Quoted in S.M. Edwards "Selling the Body, Keeping the Soul: Sexuality, Power, the Theories and Realities of Prostitution, 89-104 . In Sue Scott and David Morgan (eds.) 1993 Body Matters: Essays on the Sociology of the Body. London: Falmer Press.

Romney, Lee (2004) Weighing Strippers' Rights. Los Angeles Times. December 19 2004 Accessed Dec 282004 at http://www.latimes.com/news/local/la-mestripper19dec19,0,7233162.story?coll=la-home-local

St James Infirmary (2004 $2^{\text {nd }}$ edition) Occupational Health and Safety Handbook. 
San Francisco: Exotic Dancers Alliance and STD Prevention and Control Services of the City and County of San Francisco.

Valera, R. J, Sawyer, R.G, Schiraldi, GR (2001) Perceived Health Needs of Inner-City Street Prostitutes: A preliminary study. _Am J Health Behavior 25: 50-59.

Vanwesenbeeck I. (1994) Prostitutes' Well-Being and Risk. Amsterdam: VU University Press.

Wallace, B. (2004) Prostitution Raids in 4 San Francisco homes. San Francisco Chronicle January 23, 2004. Accessed January 302004 at http://sfgate.com/cgibin/article.cgi?file=/chronicle/archive/2004/01/23/MNGTA4GD2K1.DTL

Wallace, B and Zamora, J.H. (2004) Sex trafficking ruthless, lucrative: brothels proliferate despite crackdowns. San Francisco Chronicle January 24 2004. Accessed Jan 102005 at http://www.sfgate.com/cgi-bin/article.cgi?file=/c/a/2004/01/24/MNGU84GUJ01.DTL

Weitzer, R. (1994) Community Groups vs. Prostitutes. In C. Leigh (editor) In Defense of Prostitution. The Gauntlet. Vol 1 \#7 Pp 121-124.

Weitzer, R. (2004) Why Prostitution Initiative Misses. San Francisco Chronicle. Accessed September 292004 at http://www.sfgate.com/cgibin/article.cgi?file=/chronicle/archive/2004/09/26/INGAG8T3GP1.DTL

Zumbeck, S., Teegen, F., Dahme, B \& Farley, M. (2003) Posttraumatische Belastungsstörung bei Prostituierten - Ergebnisse einer Hamburger Studie im Rahmen eines internationalen Projektes. Zeitschrift für Klinische Psychologie Psychiatrie und Psychotherapie 51 (2): 121-136. 